\title{
Opportunities to decrease the water quality impact of spring forage crops on dairy farms
}

\author{
S.J. DENNIS ${ }^{1}$, R.W. MCDOWELL ${ }^{2}$, D.R. STEVENS ${ }^{2}$ AND D. DALLEY ${ }^{3}$ \\ ${ }^{1}$ AgResearch Ltd, Lincoln Research Centre, Private Bag 4749, Christchurch 8140 \\ ${ }^{2}$ AgResearch Ltd, Invermay Agricultural Centre, Private Bag 50034, Mosgiel 9054 \\ ${ }^{3}$ DairyNZ, Canterbury Agriculture and Science Centre, 74 Gerald St, Lincoln 7608 \\ richard.mcdowell@agresearch.co.nz
}

\begin{abstract}
Currently spring forage crops are used to manage late calving cows on the dairy platform, protect spring pasture from pugging damage, and allow the animals to feed on a mix of brassica and pasture to transition to a pasture-based diet. In addition, like winter forage crops, they could contribute considerable water quality contaminants via surface runoff. However, it may be possible to manage farms without spring forage crops. Two Southland dairy farms were used to show: 1) flowweighted mean concentrations of many water quality contaminants in surface runoff from a spring-grazed forage crop were similar to those found in studies of winter-grazed forage crops; and 2) that, using growth rate data for 2007-2012, in no year was the modelled forage crop beneficial from a feed supply perspective, and in all years the farms had similar financial performances and fewer feed deficits under all-grass management. Hence, good pasture management (e.g. avoiding treading damage using a stand-off pad and short grazing times) may negate the need for a spring forage crop, decreasing contaminant losses while not impairing farm profitability.
\end{abstract}

Keywords: surface runoff, transition diet, water quality, winter forage crop.

\section{Introduction}

Spring forage crops are an option used to manage spring feed supply and transition dairy cows that are returning to the milking platform to feed on a mix of brassica and pasture before being fed a pasture-based diet. They may also be part of a farm's pasture renewal strategy. However, like winter forage crops, they could contribute considerable water quality contaminants via surface runoff and sub-surface flow (leaching). On a kg/ ha/yr basis, losses of nitrogen $(\mathrm{N})$, phosphorus $(\mathrm{P})$ and sediment have been found to be $2-10$ times greater from winter-grazed forage crops than grazed pasture (e.g. McDowell \& Stevens, 2006; McDowell \& Houlbrooke 2009; R. McDowell unpublished data). This means that a winter-grazed forage crop can account for $>50 \%$ of the farm's $\mathrm{N}$ losses, despite only occupying $10-15 \%$ of the farm's area. However, no data are available on losses from spring forage crops.

Should losses from a spring-grazed forage crop be similar to losses from a winter-grazed forage crop, strategies would be required to mitigate this loss. The period of rumen adjustment from brassicas to pasture takes as little as 3 days (Stevens \& Corson 2002), suggesting there is little need for a spring forage crop for dietary management. However, removing a spring forage crop also removes one of the cheapest options available for feed when spring pasture production is poor, and when soil moisture is high, increases the risk of pugging of paddocks and subsequent loss of production potential. To provide enough feed for early calving, a farmer could use a stand-off area and supplement with extra feed, but the increased cost compared to a forage crop may make bringing cows home early less profitable, and increase labour requirements at this busy time of year. An alternative solution is to delay the return of the cows (provided feed is available elsewhere) until there is better pasture cover, however this will incur extra costs. A stand-off pad may still be required, but much of the feed needed can be provided by restricted (e.g., $4 \mathrm{hr}$ ) grazing periods, without significant damage to pastures. This strategy may also provide a greater feed bank for the milking cows and a higher potential peak production.

This paper presents data on the loss of contaminants in surface runoff from a spring-grazed forage crop and an adjacent grazed pasture. On the premise that losses, on a concentration basis, are high, the impact of removing the transition crop on the financial performance of a model dairy farm is also explored.

\section{Methods \\ Runoff measurements}

A northerly facing forage crop and pasture site were selected in two adjacent 4.5-5-ha paddocks within a dairy farm $c a .30 \mathrm{~km}$ east of Invercargill. The soil was a Waikiwi silt loam (NZSC: Firm Brown soil; Hewitt, 
1998). The forage crop was a mixture of Brassica napus ssp. napobrassica (swede) and Brassica oleracea L. (kale), sown in late spring 2010.

Eight plots were located at the northern end of each paddock about $10-30 \mathrm{~m}$ from the fence line in the forage crop and pasture paddocks. Slope in the selected area was $<5 \%$. Each plot was $4 \mathrm{~m}$ long by $1 \mathrm{~m}$ wide, and was bounded by wooden boards dug into the soil $25 \mathrm{~cm}$ deep leaving $5 \mathrm{~cm}$ above the soil surface. At the down-slope end the wooden board was replaced by a metal frame $\left(140^{\circ} \mathrm{v}\right.$-shape $)$ with an outlet that directed any surface runoff into a $75-\mathrm{L}$ container. Surface runoff was collected from each rainfall event, the volume from each plot measured, and a filtered $(0.45 \mu \mathrm{m})$ samples analysed for filterable reactive $\mathrm{P}$ (FRP), nitratenitrite- $\mathrm{N}(\mathrm{NNN})$ and ammoniacal-N $\left(\mathrm{NH}_{4}-\mathrm{N}\right)$, and an unfiltered sample analysed for total $\mathrm{N}$ and $\mathrm{P}$ (TN, TP) and suspended sediment (SS) using standard APHA (1998) methods.

Grazing of the forage crop paddock by 70 cows occurred on 3 to 26 of August, 2011. The pasture paddock was grazed as animals were taken off to calve a few at a time to an adjacent pasture until full rotational grazing of that paddock began on 20 August. Pasture was grazed again on 24 September. Surface runoff was collected until 14 October when the plots were removed for the forage crop paddock to be regrassed. No fertiliser was applied to either the pasture or forage crop paddocks during or for three months prior to runoff collection.

\section{Modelling}

A Southland dairy farm that had been monitored from 2007 to 2012 was modelled using Farmax Dairy Pro 6.4.0.12 (Farmax 2011). The "average" farm was modelled based on the initial farm size and the general management used over this period. The farm (140 ha) milked 392 cows producing $1263 \mathrm{~kg} \mathrm{MS} / \mathrm{ha}$. The cows (Friesian, $550 \mathrm{~kg} 1$ June liveweight, $456 \mathrm{~kg}$ MS/cow) were wintered off-farm from 18 May until 21 July. Swedes ( $8 \mathrm{ha}$ ) were grown on the milking platform, with a small quantity fed to milkers in May, but the majority used as a transition crop when the cows returned from grazing in July until the planned start of calving on 10 August. The high milk solids yield was achieved by supplementing with pasture silage, cereal silage, and barley during the milking season.

Pasture growth rates were available for the farm via weekly farm walks using a pasture plate meter from 2007 to 2012. However, these weekly records underestimated

Table 1. Flow-weighted mean concentrations (all $\mathrm{mg} / \mathrm{L}$ except suspended sediment which is $\mathrm{g} / \mathrm{L}$ ) of contaminants lost in surface runoff from four studies of winter forage crops, drained and undrained pasture plots at Tussock Creek, Southland, and in runoff from the present study. The F-statistic is given for the comparison of flow-weighted means of crop and pasture losses in the current study.

\begin{tabular}{|c|c|c|c|c|c|c|c|c|}
\hline Region \& stock type & Management & FRP & TP & SS & NNN & $\mathrm{NH}_{4}-\mathrm{N}$ & $\mathrm{TN}$ & Reference \\
\hline \multirow{2}{*}{$\begin{array}{l}\text { Northern Southland; } \\
\text { Deer }\end{array}$} & Wintered on pasture & 1.13 & 1.64 & 0.31 & 0.45 & 1.28 & 1.93 & \multirow{2}{*}{$\begin{array}{l}\text { McDowell \& Stevens } \\
\text { (2006) }\end{array}$} \\
\hline & Wintered on crop & 0.44 & 5.48 & 3.45 & 1.79 & 5.58 & 8.80 & \\
\hline \multirow[t]{3}{*}{ North Otago; Sheep } & Wintered on pasture & 0.58 & 1.18 & 0.26 & - & - & - & \multirow{5}{*}{$\begin{array}{l}\text { McDowell \& Houlbrooke } \\
\text { (2009) }\end{array}$} \\
\hline & Wintered on crop & 0.39 & 1.28 & 0.62 & - & - & - & \\
\hline & Restricted grazing on crop & 0.38 & 1.14 & 1.12 & - & - & - & \\
\hline \multirow[t]{2}{*}{ North Otago; Cattle } & Wintered on crop & 0.77 & 2.38 & 1.22 & - & - & - & \\
\hline & Restricted grazing on crop & 0.50 & 2.18 & 0.95 & - & - & - & \\
\hline \multirow[t]{4}{*}{ South Otago; Cattle } & Ungrazed pasture & 0.06 & 0.23 & 0.25 & - & - & - & \multirow[t]{4}{*}{ McDowell et al. (2005) } \\
\hline & Ungrazed crop & 0.04 & 0.17 & 0.24 & - & - & - & \\
\hline & Wintered on crop & 0.05 & 0.42 & 0.42 & - & - & - & \\
\hline & Restricted grazing on crop & 0.09 & 0.39 & 0.34 & - & - & - & \\
\hline \multirow[t]{2}{*}{ Southland; Cattle } & Drained pasture & 0.37 & 0.80 & 0.10 & 2.61 & 1.73 & 7.62 & \multirow[t]{2}{*}{ Monaghan unpublished } \\
\hline & Undrained pasture & 0.36 & 0.58 & 0.03 & 1.63 & 0.72 & 3.76 & \\
\hline \multirow[t]{3}{*}{ Southland; Cattle } & Spring grazed crop & 0.05 & 3.49 & 0.71 & 1.12 & 1.45 & 10.94 & \multirow[t]{3}{*}{ This study } \\
\hline & Spring grazed pasture & 0.10 & 0.72 & 0.05 & 0.29 & 1.12 & 4.30 & \\
\hline & F-statistic & 0.014 & $<0.001$ & $<0.001$ & 0.034 & ns & $<0.001$ & \\
\hline
\end{tabular}

FRP - filterable reactive P; NNN - nitrate-nitrite-N; NH4-N - ammoniacal-N; TN - total N; TP - total P; SS - suspended sediment. 


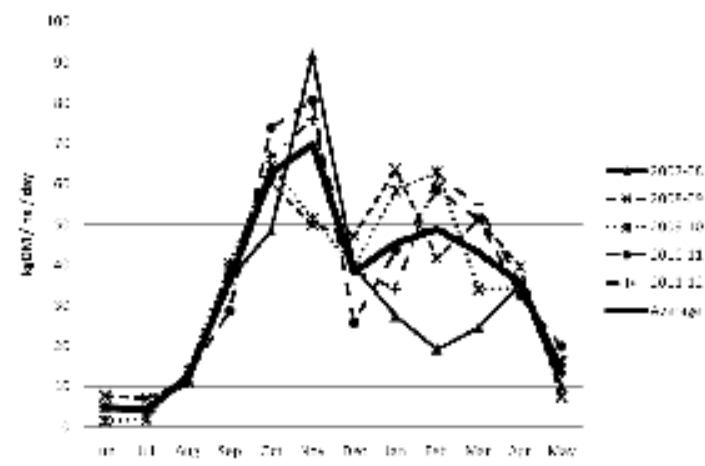

Figure 1. Monthly pasture growth rates for all years monitored (DairyNZ monitor farm data, central Southland).

true growth rates with on average 3.5 days of growth missed at the start and end of the regrowth period, or a week's growth lost each grazing rotation. The recorded pasture growth rates were therefore scaled up based on the mean grazing rotation length in that month, by a factor of $1+7 /$ (rotation length - 7), and missing values replaced by the average from all years (Fig. 1).

The farm was modelled with and without the spring crop and tested over the range of measured pasture growth profiles to examine the robustness of each approach, in three phases of modelling.

\section{A: Crop vs no crop scenarios, modelled using average pasture production}

1) The "average" farm was modelled using mean pasture growth rates (Fig. 1), to confirm that the management system was feasible and reflected average pasture covers recorded on the farm.

2) The farm was then modelled with no crop, but managed so as to maintain the same milk production curve. The larger area of pasture allowed summer silage and barley rations to be decreased and replaced with pasture. The silage allowance of dry cows in spring was increased, with the value of imported supplements kept the same as when the crop was grown.

\section{B: Fitting the model to actual pasture production over 5 years}

The two management systems (crop and no crop) were then applied, with no changes in feed allowance, to the pasture growth curves recorded for individual growing seasons between 2007 and 2012 (Fig. 1) to determine how the inter-year variation in pasture production affected the feasibility of managing the farm with or without a crop.

\section{C: Managing for a poor year}

Finally, to determine how a farmer might manage in a poor year, management practices were altered to

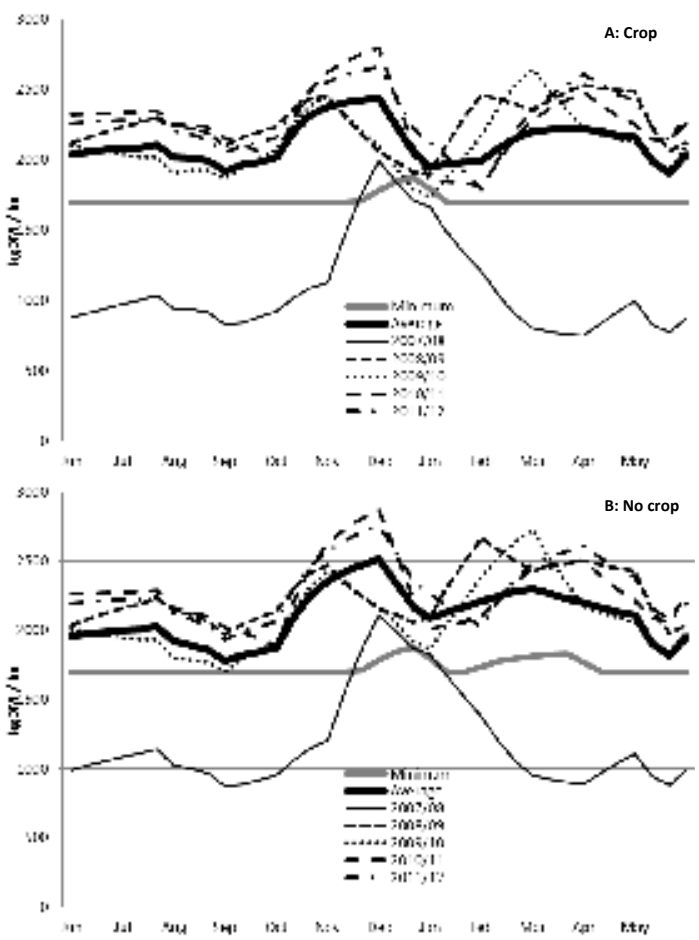

Figure 2. Average pasture cover with (A) or without (B) a spring forage crop, and with an average pasture growth curve or with pasture yields from actual years. The grey line denotes the minimum average pasture cover before cows are unable to physically consume the amount of pasture required by them to achieve the desired performance, i.e. if the pasture cover falls below the grey line there is a feed deficit.

cope with the lowest annual pasture yields (2007/08). Three short-term scenarios were tested: 1) starting with a swede crop and sowing a new crop in October; 2) starting with no crop; and 3) starting with a swede crop but anticipating a poor summer by not sowing a new crop to maximise available pasture area. Low yields were managed by purchasing more pasture silage, decreasing pasture allowance, and decreasing milk yield to just over $400 \mathrm{~kg} \mathrm{MS} / \mathrm{cow}$.

Models in phases A and B were run as long-term scenarios, while $\mathrm{C}$ was run as a short-term scenario starting with a low average pasture cover of $1700 \mathrm{~kg}$ $\mathrm{DM} / \mathrm{ha}$ in June. For financial purposes, all models were run in the same financial year (2010/11) to allow comparisons, with average costs for Southland provided by DairyNZ and Fonterra's milk price. No allowance was made for capital costs (standoff pads etc.), as any expenditure required on these would vary between farms depending on presently available infrastructure, and the need for them would also vary between soil types. Capital costs must be considered separately 


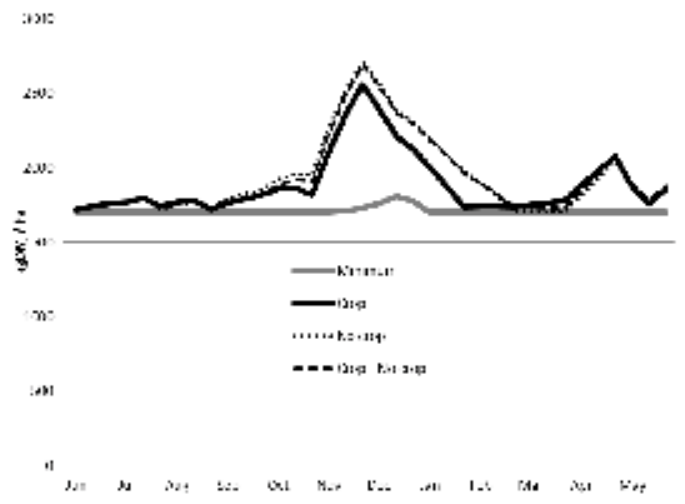

Figure 3. Pasture covers for the 2007-08 pasture yields, when run as a short-term scenario with management altered to make the farm feasible. Grey line denotes the minimum pasture cover before cows are unable to physically consume the amount of pasture required by them to achieve the desired performance.

when applying these results to any individual farm. It was presumed that removing the crop did not reduce pasture yield through additional treading damage; in practice achieving this may require a standoff pad.

\section{Results and discussion \\ Runoff study}

During the study period from August to October there was $270 \mathrm{~mm}$ of rainfall, greater than the long-term average of $226 \mathrm{~mm}$ for the same period since 1975 ( $\mathrm{min}$ $=103 \mathrm{~mm}, \max =317 \mathrm{~mm}$ ). Loads for FRP, TP, $\mathrm{NH}_{4}-\mathrm{N}$, NNN, TN and SS for the spring forage crop were 0.01 , $0.34,0.17,0.1,1.1$, and $64 \mathrm{~kg} / \mathrm{ha}$, respectively, while for the pasture the corresponding loads were $0.03,0.15$, $0.29,0.08,1.2$ and $15 \mathrm{~kg} / \mathrm{ha}$, respectively. However, due to differences in measured runoff volumes between plots $(\mathrm{CV}=41 \%)$, statistical comparisons among treatments and with other studies are best achieved with flowweighted mean concentrations (Table 1). No significant differences were noted in $\mathrm{NH}_{4}-\mathrm{N}$ concentrations between treatments. Significantly more FRP was lost from the pasture treatment than the forage treatment, while for all other analytes (NNN, TP, SS and TN) more was lost from forage crop compared to pasture.

From studies that have examined contaminant losses associated with deer, sheep or cattle grazing of forage crops in winter, the concentrations of TP and SS appear to be similar across studies (Table 1; Mann-Whitney $\mathrm{U}$ test $\mathrm{P}>0.05$ ). In contrast, erosion and the moderate anion storage capacity of the Brown soil studied (55$60 \%$ ) resulted in the greater losses of SS and TP from the forage crop than from the pasture.

Annual $\mathrm{N}$ losses from winter grazed forage crops are higher than from grazed pasture. However, it is unclear how much $\mathrm{N}$ would be lost from a spring-grazed forage crop on an annual basis compared to a winter-grazed crop. The major form of $\mathrm{N}$ lost is usually nitrate, which, being mobile, will be lost in surface runoff or sub-surface flow (leaching). Unfortunately, sub-surface measurements of $\mathrm{N}$ were not made in this study. Prior to grazing, sufficient drainage is likely to have occurred during autumn and winter to have leached the majority of $\mathrm{N}$ mineralised as a result of cultivation and sowing the crop. Grazing results in substantial N returned to the soil via urine patches that would be lost as there are no actively growing plants to take it up. However, there is likely to be less drainage following grazing of a spring than winter-grazed crop before a new crop or pasture is available to take up $\mathrm{N}$ (i.e., much shorter fallow period).

There are a number of mitigation practices that have been trialled for winter forage crops that may be effective in decreasing losses from spring-grazed forage crops. Restricted (4-6 hr) grazing has been shown to decrease nitrate, TP and SS losses by $25-50 \%$ compared to unrestricted systems (Christensen et al. 2010; McDowell et al. 2005). Other strategies include: the placement of forage crops in flat areas well away from receiving surface waterways (including drains); the use of buffer strips or riparian areas downslope to increase infiltration (decreasing runoff); and the application of nitrification inhibitors to decrease nitrate leaching during winter drainage. All these strategies may incur financial or labour costs, which will strongly influence whether they are adopted (Bewsell \& Brown 2009). Another strategy may be to remove the unnecessary spring forage crop from the system.

\section{Modelling}

\section{A: Crop vs no crop with average pasture production}

The whole-farm pasture covers indicate that the farm may be run with or without the forage crop when pasture growth is average (Fig. 2A and 2B, thick black lines). The grey line displays the minimum average pasture cover that is feasible at that time of year without running into a feed deficit. The spring forage crop option creates more surplus pasture in early spring, but not in late December. Removing the crop leads to low covers in late August, but without a crop more feed is available in summer due to the larger area of pasture available for grazing.

The scenario with no crop was more profitable, yielding a net operating profit of $\$ 678000$ compared with $\$ 656000$ with the crop. This $\$ 22000$ profit difference reflected the added cost of sowing a crop and re-grassing after it, since the quantity of imported supplements and the milk yield were kept the same. In an average year, the most profitable farm management option was to have no forage crop, and it was possible to maintain the same level of production as with a forage 
crop without importing any additional supplements.

\section{B: Fitting the model to actual pasture production over 5 years}

There was a consistent advantage to the no-crop scenario in every year, as represented by the modelled pasture covers when the same farm management was applied to each year of measured pasture growth (Fig. 2).

The all-pasture system had the greatest available pasture at the most critical pinch period of the year late December, making this management option the most secure against variations in pasture yield between years, as it was less likely to run into feed deficit. Feed supplies were very tight at this period in 2008/09, $2009 / 10$ and $2010 / 11$, with the 2009/10 year actually running into a feed deficit. However in all three of these years the farm had sufficient pasture without a crop, although feed supply was tight in spring in 2009/10. The 2011/12 season had no shortage of feed under either management system, while the 2007/08 season had severe feed shortages (note that the actual covers plotted are unrealistically low for this one year due to the model being run in long-term mode; the results for this one year simply show there was a severe feed shortage but do not reflect the actual covers expected on-farm).

\section{C: Managing for a poor year}

The modelled pasture covers in 2007/08 are unrealistically low (Fig. 2) under average management. This year was selected for a more detailed examination of how a farmer might actually manage the low pasture growth rates. Pasture allowances were deliberately chosen to keep pasture covers (Fig. 3) very close to the minimum that would be feasible, to minimise any potential management bias. The crop scenario was the poorest performer financially, with an operating profit of $\$ 465000$. Milk solids production was reduced to $400 \mathrm{~kg} \mathrm{MS} / \mathrm{cow}$. In total, 330 tonnes of pasture silage and 167 tonnes of barley had to be purchased, compared with 205 and 142 tonnes in an average year. The crop provided valuable feed in spring, but sowing the following year's crop ( $8 \mathrm{ha}$ ) in October reduced available grazing area for the remainder of the year, restricting summer feed. The no-crop scenario had an operating profit of $\$ 503000$. Some $366 \mathrm{t}$ of pasture silage and $167 \mathrm{t}$ of barley had to be purchased in this scenario, but the additional supplement cost less than the crop. The greater availability of pasture in summer resulted in a milk solids production of $402 \mathrm{~kg} \mathrm{MS} / \mathrm{cow}$.

The most profitable scenario used a spring forage crop that was not replaced for the following year. Operating profit was $\$ 515000$, milk yield was $403 \mathrm{~kg}$ MS/cow, and only 274 and 167 tonnes of silage and barley had to be purchased.
In a year of extremely poor production, having a forage crop is beneficial in spring. However, the benefit is outweighed by the detrimental effect of having to grow next year's forage crop through the summer, resulting in summer feed shortages, and requiring a large amount of imported supplement to be purchased. Without the forage crop, slightly more imported feed must be purchased overall, and this is required in spring rather than summer, but, as the overall cost of this is estimated to be less than the cost of establishing a forage crop, the farm without the crop has a profit that is $\$ 38000$ higher. As feed prices are volatile during feed shortages it is impossible to be precise about the relative profitability of the scenarios. The relative availability and therefore price of feed in spring, as opposed to summer, in a poor year is questionable also. The farmer without a crop may also have the option to delay the return of late calving cows if grazing is available, which could be more cost-effective and require less labour input (although this option was not modelled).

The spring forage crop was only financially beneficial in a poor year if the farmer had the foresight to recognise that the summer was going to be bad, and did not sow a forage crop for next year, giving him the benefit of both a crop in spring and pasture in summer. However, this decision needs to be made in September or early October, which is unlikely as it is questionable that the long-term seasonal weather outlook is reliable enough for a farmer to make such a major change in their management. This scenario is therefore probably not realistic.

The no-crop management system does reduce the amount of regrassing on the property. It may be more realistic to presume that the area that is in crop will be renewed grass to grass. This would add a cost of around $\$ 1000$ per hectare, or $\$ 8000$, reducing the $\$ 22000$ profit difference to $\$ 14000$. However, it would still be more financially beneficial to not crop.

Although this paper focusses on spring forage crops, the same crops are often used to also transition cows to a brassica diet at the end of lactation, which is an important management strategy to ensure cows are able to put on condition while grazing off-farm over winter. Removing spring forage crops would also prevent this use of the crop, which must also be considered. Autumn transition can be achieved in a number of ways that do not involve actually sowing a brassica crop on the milking platform. Cows can be fed pasture plus silage in late lactation, then move to brassica plus silage off-farm initially, using silage to provide a transition. Alternatively, cows can be fed pasture plus brassica initially on the winter grazing property rather than on the milking platform. This would require good relationships with the grazier.

In reality a farmer will consider a much wider range of 
factors than the narrow operating profit approach used in this paper when making their decisions, including capital costs, practical management considerations (such as the regrassing programme or the potential to damage pasture by pugging if spring is wet), workforce skills and (critically) what respected peers are doing. This paper demonstrates the technical feasibility of removing spring forage crops from this system, but management decisions for an individual farm will require wider considerations than were possible within the scope of this paper.

\section{Conclusions}

This study showed that the loss of phosphorus and sediment from a spring-grazed forage crop were greater than an adjacent pasture used for light grazing and calving. The potential to remove a spring-grazed forage crop was modelled showing no reason, from either a feed security or financial viewpoint (based on the costs used), to have a spring forage crop in this environment. In all years all-pasture management was both more profitable and provided more feed at the key pinch period of late December. This paper demonstrates that it is feasible to eliminate spring forage crops from the modelled dairy farm while maintaining both profitability and feed security, and also potentially decreasing the water quality footprint. This shows the strategy is worth consideration, although a wider range of factors must be considered to determine whether this is practical on an individual farm.

\section{ACKNOWLEDGEMENTS}

This work was possible due to the financial support of DairyNZ and MSI contract C10X1006 (Clean Water, Productive Land). Farm data for modelling was provided by DairyNZ from their monitor farm programme, and we are grateful to both DairyNZ and the farmer for access to this.

\section{REFERENCES}

APHA (American Public Health Association). 1998. Standard methods for the examination of water and wastewater. 20th ed. American Public Health Association, American Water Works Association and Water Environment Federation, Washington DC, United States.
Bewsell, D.; Brown, M. 2009. Involvement and decision making on farm: the use of wintering feedpads and nitrogen inhibitors on dairy farms in New Zealand. Extension Farming Systems Journal 5: 81-90.

Christensen, C.L.; Hanly, J.A.; Hedley, M.J.; Horne, D.J. 2010. Using duration-controlled grazing to reduce nitrate leaching from dairy farms. In: Currie, L.D.; Christensen, C.L. eds. Farming's future: minimising footprints and maximising margins. $p$. 46-52, Occasional Report No. 23 of the Fertilizer and Lime Research Centre, Massey University, Palmerston North, New Zealand.

Farmax 2011. Farmax Dairy Pro 6.4.0.12: AgResearch Science Edition. Available at: www.farmax.co.nz accessed Jun, 2012.

Hewitt, A.E. 1998. New Zealand soil classification. Manaaki Whenua Press, Lincoln.133 pp.

McDowell, R.W.; Drewry, J.J.; Muirhead R.W.; Paton, R.J. 2005. Restricting the grazing time of cattle to decrease phosphorus, sediment and E. coli losses in overland flow from cropland. Australian Journal of Soil Research 43: 61-66.

McDowell, R.W.; Houlbrooke, D.J. 2009. Management options to decrease phosphorus and sediment losses from irrigated cropland grazed by cattle and sheep. Soil Use and Management 25: 224-233.

McDowell, R.W.; Stevens D.R. 2006. Potential waterway contamination associated with wintering deer on pastures and forage crops. New Zealand Journal of Agricultural Research 51: 287-290.

Stevens, D.R.; Corson I.D. 2002. Effects of winter feed type on feed intake during the transition back to spring pasture. Nutrition and Management of Deer on Grazing Systems. Grassland Research and Practice Series 9: 45-50. 